\title{
Investigation of the Effects of Land Use on Chemical Water Quality Parameters; A Case Study of Başkonuş-Meydan Dam Lake in Kahramanmaraş
}

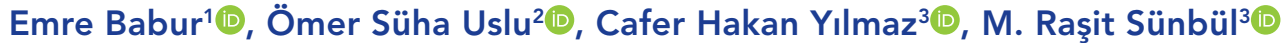

Cite this article as: Babur, E., Uslu, O.S., Yilmaz, C.H., \& Sunbul, M.R. (2021). Investigation of the effects of land use on chemical water quality parameters; a case study of Başkonuş-Meydan Dam lake in Kahramanmaraş. Aquatic Sciences and Engineering, 36(1), 22-28.

ORCID IDs of the author: E.B. $0000-0002-1776-3018$ Ö.S.U. 0000-0003-0858-0305; C.H.Y. 0000-0003-3680-453X; M.R.S. 0000-0003-2093-9659

${ }^{1}$ Kahramanmaras Sutcu Imam University, Faculty of Forestry, Soil Science and Ecology, Turkey

${ }^{2}$ Kahramanmaras Sutcu Imam University, Agriculture Faculty,

Field Crops Department, Turkey

${ }^{3}$ East Mediterranean Transitional Zones Agricultural Research Institute, Kahramanmaraş, Tukey

\section{Submitted:}

04.04.2020

Revision Requested: 25.06.2020

Last Revision Received: 25.06.2020

Accepted:

09.07.2020

Online published:

21.10.2020

Correspondence:

Emre Babur

E-mail:

emrebabur@ksu.edu.tr

(C) Copyright 2021 The Author(s) Available online at

https://dergipark.org.tr/ase

\begin{abstract}
Water quality is in constant interaction with and changed according to time and place through natural and anthropogenic factors. It is also known that land use has a significant impact on water quality parameters. In this study, it was aimed to determine the effects of different land-use types (Forest, range and riparian) on water quality and which land-use type supports the most suitable drinking water for watersheds in the Başkonuş Plateau in Kahramanmaraş Province. The field studies were carried out in May 2019, and 2 sampling points were selected from each of the land-use types. Chemical properties ( $\mathrm{pH}, \mathrm{EC}$ ) and some element concentrations (19 elements such as Al, As, $\mathrm{Cu}, \mathrm{B}, \mathrm{Zn}, \mathrm{Fe}, \mathrm{P}, \mathrm{Cd}, \mathrm{Ca}, \mathrm{Co}, \mathrm{Cr}, \mathrm{Pb}, \mathrm{Mg}, \mathrm{Mn}, \mathrm{Mo}, \mathrm{Ni}, \mathrm{K}, \mathrm{Na}$, and $\mathrm{S}$ ) were investigated by using an ICP-OES. According to the results, the water obtained from forest areas is more suitable for drinking, having drinking water quality standards with a high $\mathrm{pH}$ value (7.59), and the Sulfur concentration of water obtained from range area $(26.72 \mu \mathrm{g} \mathrm{S} / \mathrm{L})$ exceeded and did not comply with drinking water quality standards. When the chemical characteristics of the Meydan Dam were examined according to the regulated water quality standards declared in water pollution laws, it is clear that the dam basin has a high water quality standard (Class I). Therefore, a larger dam that can be built in this basin would be able to supply quality water that the Kahramanmaraş metropolitan municipality needs. Consequently, before deciding on the construction of the dam for drinking water, land-use maps would be created in the basins, and the selection of basins that have dense and qualified forestland would provide quality water.
\end{abstract}

Keywords: Chemical water quality, forest, Kahramanmaraş, Land use, parameters, range, riparian

\section{INTRODUCTION}

Water quality is in constant interaction with and changed by natural and anthropogenic factors. Among the natural phenomena, the amount of precipitation, river bed and basin characteristics (slope, length, etc.), geological structure, soil type, plant species, and stand closure are major factors that significantly affect water quality. Many of these factors are also changed by humans, causing negative effects on water quality in rivers or lakes. For example, conver- sion of forests to agriculture or settlements prevents access to quality water due to using pathogens, pesticides, domestic waste, heavy metals, oils, salts, and road construction in agriculture and settlements areas.

Land-use types in a catchment basin significantly affect the water quality of the basin. It is well-known that there is a strong relationship between land use (agriculture, range, forest, settlement, etc.) and water quality. Moreover, some studies have reported that forest land in- 
creases the water quality and quantity in a watershed basin (Altun, Kezik, Kara, \& Babur, 2016; Babur \& Kara, 2017). On the other hand, the studies investigating the relationship between land use and water quality due to the need for quality and a sufficient amount of water are gradually increasing as a result of pollution or the reduction of water resources because the increase in human activities in different land-use leads to changes in water quality (Sliva \& Williams, 2001; Ngoye \& Machiwa, 2004; Tokatli, Solak, \& Yılmaz, 2020). However, land-use changes (such as removal or change of vegetation) and management practices (the establishment of road and settlement areas, agricultural management, etc.) are also important factors affecting water quality (Yong \& Chen, 2002). Guo, Ma, \& Zhang (2009) revealed that land use and vegetation cover the effects of water quality. This study stated that there is a significant amount of total nitrogen and phosphorus transitions from meadows to streams. Cao, Li, Wang, Zhao, \& Wang (2012) examined the relationship between land-use type and water quality. They noticed that there are significant differences in the water quality parameters of cultivated areas, meadows, and forest areas in terms of TN (total nitrogen), TP (Total phosphate) coliform bacteria. Huang et al. (2013) found significant differences in some water quality indicators among settlement areas, meadows, and forests in their study. In all of these studies, the effects of land use in watersheds on water quality were specifically investigated.

Several studies have emphasized that land use has a significant impact on the chemical properties of water quality (Peierls, Caraco, Pace, \& Cole, 1991; Hunsaker \& Levine, 1995; Puckett, 1995; Howarth et al., 1996; Allan, Erickson \& Fay, 1997). For example, the nitrogen and nitrate concentrations in water increased due to the increase of meadow areas in a basin (Jordan, Correl, \& Weller, 1997). However, Allan et al. (1997) stated that the best properties in terms of habitat quality and biotic integrity are in agricultural land. Urbanization and intensive agricultural practices is a large portion of the negative relations between land use and water quality (Baker, 2005). The decrease of plant communities covering the soil surface in an area increases the sediment loss with the surface flow in the catchment basin while decreasing the infiltration capacity (Walling \& Fang, 2003). Considering that such studies are lacking in developing countries, it is important to develop models that reveal the relationships between land use and water quality.

Kahramanmaraş/Başkonuş Plateau has great importance for the region in terms of climate, ecology, natural beauty, and very rich vegetative biodiversity. Since the areas where the research was conducted are far from anthropogenic effects, they can be used as drinking water basins if needed in the future. In this study, it was aimed to determine the effects of different land uses on water quality and which land-use type support the most suitable drinking water for the watershed in the Başkonuş Plateau in Kahramanmaraş Province. It was investigated how the rainfall drained from litters and soils formed under different land uses affect the water quality during infiltration. For this purpose, soil sections with a certain surface area were taken from the lands and placed in suitable drainage containers. The water filtered as a result of an artificial sprinkler applied to the soil sections was collected and prepared for analysis. From the data obtained as a result of this study, the most suitable land-use type will be determined, and the study will contribute to the preference of water collection basins through the construction of drinking water reservoirs.

\section{MATERIALS AND METHODS}

\section{Study area}

The field study was carried out in the forest, range and riparian areas around the Meydan pond located within the boundaries of the Başkonuş Forest Operation of Kahramanmaraş Forest Regional Directorate (Figure 3a, 3b, and 3c). The research area is approximately $50 \mathrm{~km}$ from Kahramanmaraş Province. In this study, the areas where topographic, geological, climatological, and geomorphological features are similar were chosen to reveal the effects of different land uses on water quality. The water collection basin of the study site, which is selected from typical karstic areas, covers an area of 105 hectares in total $\left(37^{\circ} 34^{\prime} 12^{\prime \prime}-\right.$ $\left.37^{\circ} 34^{\prime} 51^{\prime \prime} \mathrm{N} ; 36^{\circ} 35^{\prime} 13^{\prime \prime}-36^{\circ} 35^{\prime} 22^{\prime \prime} \mathrm{E}\right)$. The average elevation of the area is $1200 \mathrm{~m}$, the general aspect is north, and the average slope is $50 \%$. The study site is shown on the map in Figure 1.

The vegetation type of the research area consists of black pine (Pinus nigra Arn.), fir (Abies cilicica subsp. cilicica), and cedar (Cedrus libani A. Rich.) forest trees. There are Salvia, Trifolium, Cynodon plants, etc in range areas and reeds in riparian areas (Anonymous, 2012). The field studies are shown in Figure 2.

\section{Field study and sampling}

In this research, field studies were carried out in May 2019. In order to carry out this research, 2 sampling points were selected from each of the forest, range, and riparian areas. At the sample points, a $25 \times 25 \times 15$ soil section was removed without disturbing the litter layer and structure and placed in the fit size plastic containers with bottom leaking filters (Figure 3 and 4). 2 It of ultra-pure distilled water was added to each soil section with an artificial rain system. Then, the water leaking into the boilers placed under the buckets was collected. Afterward, the water samples were filtered in such a way as to make their volumes to $100 \mathrm{ml}$ with ultra-pure distilled water.

\section{Chemical and elemental parameters}

The $\mathrm{pH}$ values of water samples were measured with an Orion 250A meter, electrical conductivity (EC) with an Amber Science

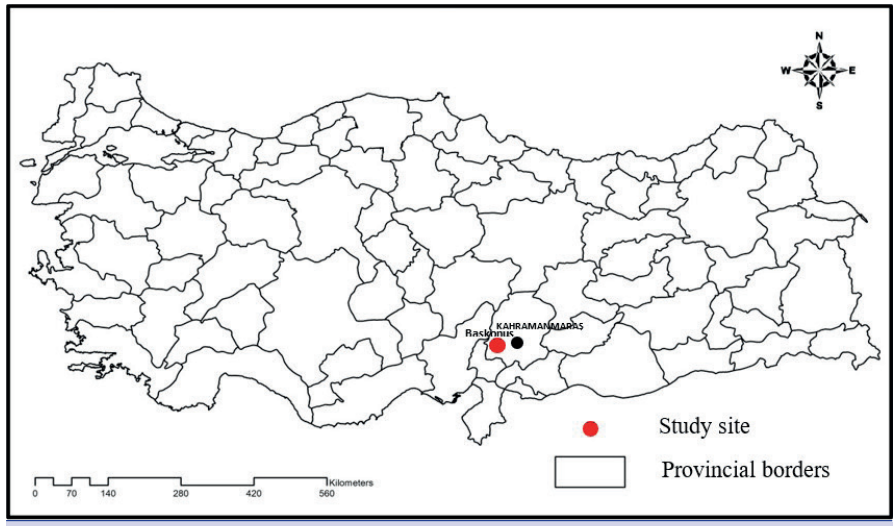

Figure 1. Location of the study site. 


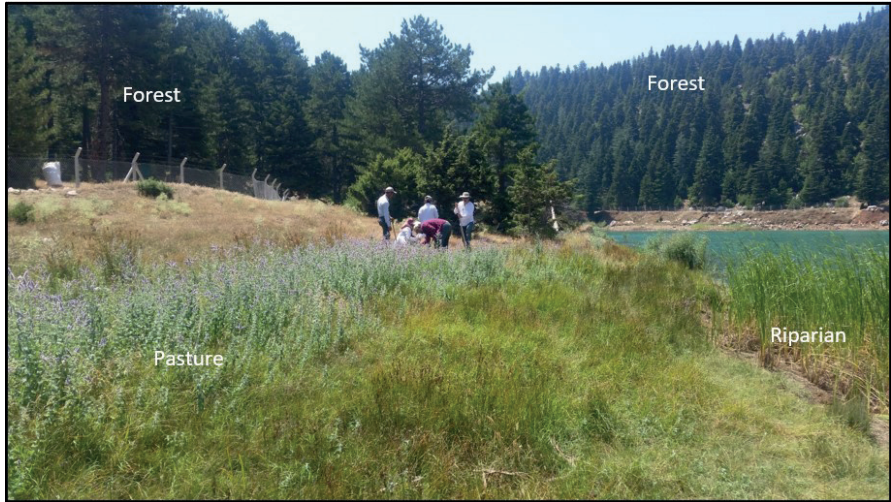

Figure 2. The appearance of forest, range and riparian zones in the research areas (Photo: Emre Babur, 2019).

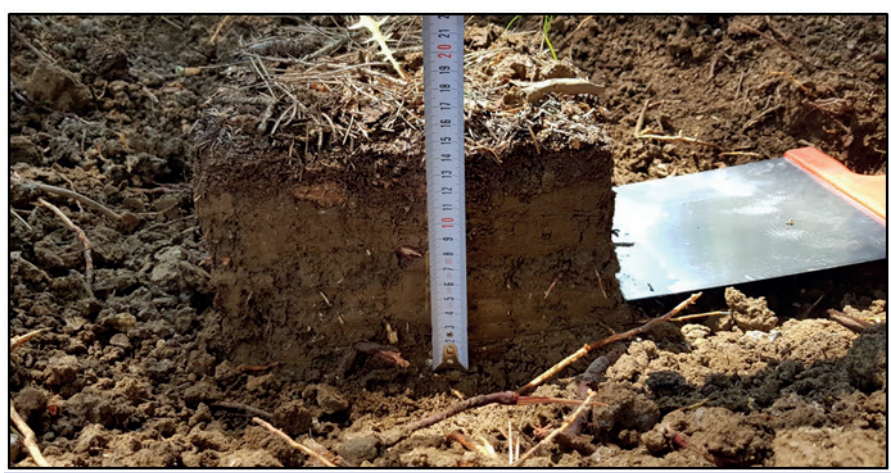

Figure 3. The process of taking soil sections from the field (Photo: Emre Babur, 2019).

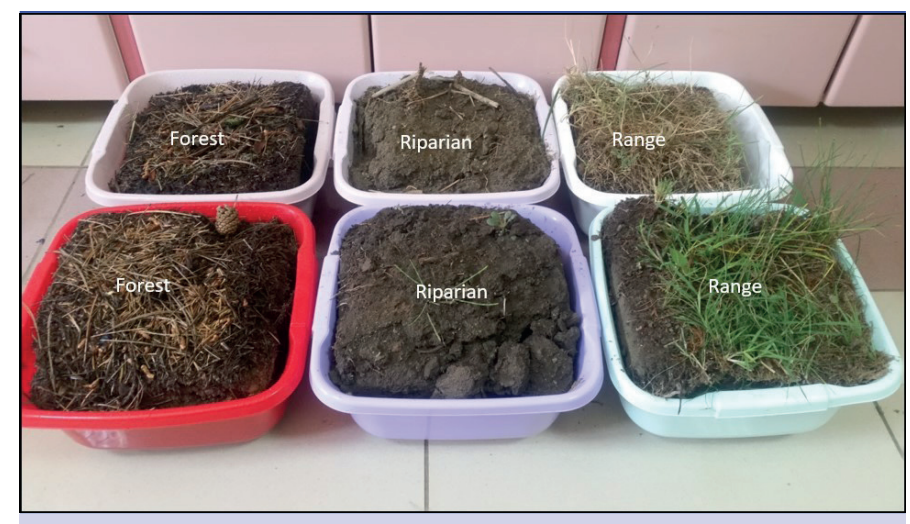

Figure 4. Soil sections taken from different land-use types (Photo: Emre Babur, 2019).

2052 meter with the method of glass electrode (Gülçür, 1974). The element levels (Al, As, Cu, B, Zn, Fe, P, Cd, Ca, Co, Cr, Pb, $\mathrm{Mg}, \mathrm{Mn}, \mathrm{Mo}, \mathrm{Ni}, \mathrm{K}, \mathrm{Na}$, and $\mathrm{S}$ ) in the samples were determined by using the "Agilent 5100 ICP-OES" device at the East Mediterranean Transitional Zones Agricultural Research Institute. The element analyses were recorded as means triplicate measurements (EPA, 1998; 2001).

\section{Statistical analysis}

The average, maximum, and minimum values and standard errors of the water samples values were determined by using the SPSS 15.0 program. The average values of different water samples obtained from the different land-use types were compared by using ANOVA and Duncan test.

\section{RESULTS AND DISCUSSION}

The mean values and standard errors of the chemical properties of water samples obtained from different land uses have been determined (Table 1). Comparisons and classifications of the mean values of water chemical parameters were made based on the Surface Water Quality Management Regulation, Water Pollution Control Regulation, Maximum Permissible Value, Recommended Value, and Regulations on Human Consumption Water.

Acidic water or basic water occurs with increasing or decreasing hydrogen ion concentrations in water (Göksu, 2003). It has been determined that there is a significant difference in the $\mathrm{pH}$ of the water obtained from different land uses $(p<0.001)$. While the highest $\mathrm{pH}$ value was found in riparian areas with a value of 7.63 , the lowest $\mathrm{pH}$ value was found in range areas with a value of 7.38. However, the $\mathrm{pH}$ value of the water samples taken from the Meydan pond was determined to be lower (7.08) compared to other land uses (Table 1). The $\mathrm{pH}$ is the most important factor for chemical and biological systems in water ecosystems (Atay and Pulatsü, 2000). According to the inland water quality standards, the high-quality water limits given for the $\mathrm{pH}$ parameter are between 6.5 and 8.5 (Table 2). The $\mathrm{pH}$ values of water obtained from all three landuse types were determined to be in the I. and II. water quality classes of the RCWP and SWOMR. Also, all of these water samples are suitable for drinking-use according to TS-266 and RWHC (Tables 1 and 2).

According to electrical conductivity (EC), the mean EC values of water samples obtained from the different land-use types were found significantly different $(p<0.001)$. The highest EC value was found in riparian areas with a value of $248.74 \mu \mathrm{s} / \mathrm{cm}$, and the lowest was found in forest areas with a value of $53.25 \mu \mathrm{s} / \mathrm{cm}$ (Table 1). The EC values of water samples were found to be in the I. and II. water quality classes, and they are suitable for drinking-use according to TS-266 and RWHC (Tables 1 and 2).

The $\mathrm{Ca}^{+2}, \mathrm{Mg}^{+2}$, and $\mathrm{K}^{+}$values of the water samples were found statistically different from each other. In terms of $\mathrm{Ca}^{+2}$ average values, $62.47 \mathrm{mg} \mathrm{Ca}^{+2} / \mathrm{L}$, the highest value, was found in the range and $14.39 \mathrm{mg} \mathrm{Ca}^{+2} / \mathrm{L}$, the lowest, in the forest areas. The concentration of $\mathrm{Mg}^{+2}$ was found to be the highest in the riparian areas with a value of $9.27 \mathrm{mg} \mathrm{Mg}^{+2} / \mathrm{L}$ and the lowest concentration in forest areas with a value of $2.03 \mathrm{mg} \mathrm{Mg}^{+2} / \mathrm{L}$. The $\mathrm{K}^{+}$concentration was found to be the highest in the forest area with a value of $4.98 \mu \mathrm{g} \mathrm{K}^{+} / \mathrm{L}$ and the lowest in the riparian area with a value of $1.93 \mu \mathrm{g} \mathrm{K}^{+} / \mathrm{L}$ (Table 1). $\mathrm{Ca}^{+2}, \mathrm{Mg}^{+2}$, and $\mathrm{K}^{+}$concentrations of water samples are below the maximum limit values in all regulations and TS-266 (Table 1 and 2). In terms of human health, $\mathrm{Ca}^{+2}, \mathrm{Mg}^{+2}$, and $\mathrm{K}^{+}$concentrations should be at the recommended levels in drinking water.

In terms of total hardness in the water samples $(\mathrm{Ca}+\mathrm{Mg})$, the highest mean value was found in range areas with a value of 
Table 1. Some chemical water quality parameters measured from different land-use types.

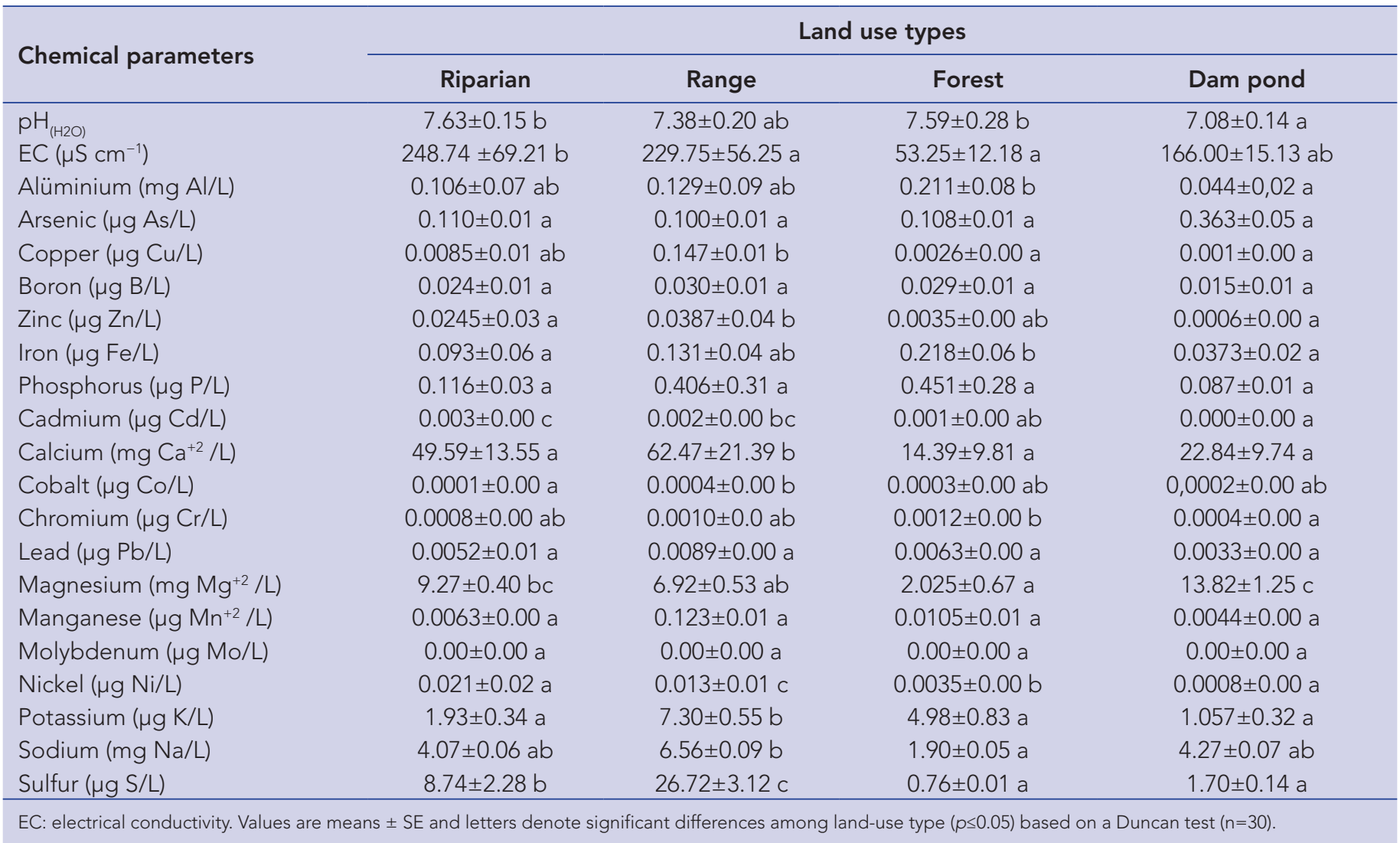

$69.39 \mathrm{mg} / \mathrm{L}$ while the lowest hardness level was found in water obtained from forest areas with a value of $16.42 \mathrm{mg} / \mathrm{L}$. The mean hardness value of the water samples of the riparian areas was found to be $59.29 \mathrm{mg} / \mathrm{L}$ (Table 1). According to the French hardness level, the most suitable water was determined to be the water obtained from the forests. This is thought to be since the cation exchange capacity and the amount of organic matter of the forest soils are higher than other land uses. On the other hand, domestic wastes and agricultural areas are known to increase the hardness of water and level of pollutants in Turkey (Bulut, Atay, Uysal, Köse, \& Çınar, 2010).

Statistically significant differences were found in phosphorus concentrations of the water samples according to the different land uses $(p<0.05)$. The highest amount of phosphorus was found in water samples obtained from forest areas $(0.451 \mu \mathrm{g} P / \mathrm{L})$, while the lowest amount of phosphorus was found in riparian areas ( $0.116 \mu \mathrm{g} P / \mathrm{L})$. Phosphorus concentrations in the range $(0.406 \mu \mathrm{g}$ $P / L)$ is of an average value close to those in forest areas. According to the regulation classes, water samples obtained from riparian areas are in 2nd quality class, and samples obtained from rangeland and forests are in the 3rd quality class in terms of phosphorus. It is well known, high concentrations of nitrogen and phosphorus cause eutrophication in water (NSTC, 2003). Therefore, it is important to keep the phosphorus concentration in drinking water below the eutrophication threshold value (Pers, 2005). The sources of phosphorus in the catchment basin are materials of organic origin. Therefore, there is no inorganic phospho- rus entry into the area, the lower concentration of phosphorus determined in the basin. Otherwise, using organic phosphate fertilizers, cadmium should be accumulated on the soil surface and also be moved to groundwater resources (Emiroğlu et al., 2013).

In terms of the concentrations of some heavy metals in water samples, the mean aluminum (Al) amount was found the highest in the forest area with a value of $0.211 \mathrm{mg} / \mathrm{L}$ and the lowest in the riparian areas with a value of $0.106 \mathrm{mg} / \mathrm{L}$. This value in rangeland areas was found to be $0.129 \mathrm{mg} / \mathrm{L}$. These values showed that land-use types statistically effect Al contents ( $p<0.001$; Table 1). Also, it was determined that the Al values of water samples obtained from all land-use types are in the 1st water quality class with all regulations such as TS-266, RCWP, and SWOMR (Table 2).

No statistically significant difference was found in boron concentrations of water samples from different land uses ( $p>0.05)$. Boron concentrations of water were very close to each other. Boron amounts in the water samples obtained from riparian, rangeland, and forest areas are 0.024, 0.030, and $0.029 \mu \mathrm{g} \mathrm{B} / \mathrm{L}$, respectively (Table 1). The boron concentration in water samples were found below drinking water threshold values shown in TS-266 and RWHC (Table 2).

Significant differences were found in iron concentrations of water samples in different land uses $(p<0.001)$. While the highest Fe concentration was found in forest areas with a value of $0.218 \mu \mathrm{g}$ $\mathrm{Fe} / \mathrm{L}$, the lowest concentration $(0.093 \mu \mathrm{g} \mathrm{Fe} / \mathrm{L})$ was found in riparian areas. However, no significant difference was found be- 
Table 2. Regulations about Water Quality Parameters (Anonymous 2016a; 2016b; 2016c; TSE, 1997).

\begin{tabular}{|c|c|c|c|c|c|c|c|}
\hline \multirow{2}{*}{$\begin{array}{l}\text { Water quality parameters } \\
\text { A) Chemical parameters }\end{array}$} & \multicolumn{4}{|c|}{$\begin{array}{c}\text { RCWP, SWQMR } \\
\text { Water quality classification }\end{array}$} & \multicolumn{2}{|c|}{ TS-266 } & \multirow{2}{*}{ RWHC } \\
\hline & I & II & III & IV & RV & MPV & \\
\hline 1) $\mathrm{pH}_{(\mathrm{H} 2 \mathrm{O})}$ & $6.5-8.5$ & $6.5-8.5$ & $6.0-9.0$ & $>6.0-9.0$ & $6.5-8.5$ & $6.5-9.2$ & $\leq 6,5-9,5 \leq$ \\
\hline 2) $E C(\mu \mathrm{s} / \mathrm{cm})$ & - & - & - & - & 400 & 2000 & 2500 \\
\hline \multicolumn{8}{|c|}{ B) Inorganic chemical parameters } \\
\hline 1) Aluminium (mg Al/L) & 0.3 & 0.3 & 1 & $>1$ & 0.05 & 0.2 & 0.2 \\
\hline 2) Arsenic ( $\mu \mathrm{g} A s / L)$ & 20 & 50 & 100 & $>100$ & & & 10 \\
\hline 3) Copper ( $\mu \mathrm{g} \mathrm{Cu} / \mathrm{L})$ & 20 & 50 & 200 & $>200$ & 20 & 200 & 20 \\
\hline 4) Boron ( $\mu \mathrm{g} B / L)$ & $1000^{e}$ & $1000^{e}$ & $1000^{e}$ & $>1000$ & $<1000^{e}$ & 1 & 1 \\
\hline 5) Zinc ( $\mu g$ Zn/L) & 200 & 500 & 2000 & $>2000$ & 100 & 5000 & - \\
\hline 6) Iron ( $\mu \mathrm{g} \mathrm{Fe} / \mathrm{L})$ & 300 & 1000 & 5000 & $>5000$ & 50 & 200 & 200 \\
\hline 7) Phosphorus (mg P/L) & 0,02 & 0,16 & 0,65 & $>0,65$ & & & \\
\hline 8) Cadmium ( $\mu \mathrm{g} \mathrm{Cd/L)}$ & 3 & 5 & 10 & $>10$ & $\leq 3$ & 10 & 5 \\
\hline 9) Calcium (mg Ca+2 /L) & - & - & - & - & 100 & 200 & - \\
\hline 10) Cobalt ( $\mu \mathrm{g} \mathrm{Co/L)}$ & 10 & 20 & 200 & $>200$ & - & - & - \\
\hline 11) Chromium ( $\mu \mathrm{g} \mathrm{Cr}+6 / L)$ & Çok az & 20 & 50 & $>50$ & Çok az & 50 & 0,05 \\
\hline 12) Lead ( $\mu \mathrm{g} \mathrm{Pb/L)}$ & 10 & 20 & 50 & $>50$ & 10 & 50 & 10 \\
\hline 13) Magnesium (mg Mg & - & - & - & - & 30 & 50 & - \\
\hline 14) Manganese ( $\mu \mathrm{g} \mathrm{Mn+2/L)}$ & 100 & 500 & 3000 & $>3000$ & 20 & 50 & 50 \\
\hline 15) Molybdenum ( $\mu \mathrm{g} \mathrm{Mo} / \mathrm{L})$ & - & - & - & - & - & - & - \\
\hline 16) Nickel ( $\mu \mathrm{g} \mathrm{Ni/L)}$ & 20 & 50 & 200 & $>200$ & - & 50 & 20 \\
\hline 17) Potassium (mg K+ /L) & - & - & - & - & 10 & 12 & - \\
\hline 18) Sodium (mg Na/L) & 125 & 125 & 250 & $>250$ & $<250$ & 250 & 200 \\
\hline 19) Sulfur ( $\mu \mathrm{g} \mathrm{S/L)}$ & 2 & 2 & 10 & $>10$ & & & \\
\hline
\end{tabular}

tween manganese concentrations and land use differences ( $P>0.05)$. In water samples, manganese concentrations were observed from highest to lowest in rangeland, forest, and riparian areas, respectively (Table 1). The iron, manganese, and potassium concentration in water samples found are in the 1st water quality class for drinking water according to all regulations like TS-266, RCWP, SWOMR, and RWHC (Table 2).

As a result of comparing average values of arsenic, copper, zinc, cadmium, cobalt, molybdenum, nickel, chromium, and lead of the water samples obtained from different land uses; the concentrations of copper, zinc, cadmium, cobalt, nickel, and chromium are affected by land-use differences, but those of arsenic, lead, and molybdenum are not.

The highest heavy metal concentrations were found in the riparian area with values of $0.003 \mu \mathrm{g} \mathrm{Cd} / \mathrm{L}, 0.110 \mu \mathrm{g} \mathrm{As} / \mathrm{L}$, and $0.021 \mu \mathrm{g}$ $\mathrm{Ni} / \mathrm{L}$; these values in rangeland were $0.147 \mu \mathrm{g} \mathrm{Cu} / \mathrm{L}, 0.039 \mu \mathrm{g}$ $\mathrm{Zn} / \mathrm{L}, 0.0004 \mu \mathrm{g} \mathrm{Co} / \mathrm{L}$, and $0.0089 \mu \mathrm{g} \mathrm{Pb} / \mathrm{L}$, and the value in forest land was $0.0012 \mu \mathrm{g} \mathrm{Cr} / \mathrm{L}$ (Table 1). All these heavy metal values comply with the average values reported in the international water quality regulations and TS-266. This study noticed that the water samples obtained from different land-use types were found in the $1^{\text {st }}$ water quality class in terms of the heavy metal concentrations (TS-266, RCWP, SWQMR, and RWHC). Tokatli
(2019) noticed that some heavy metals such as cadmium, lead, and arsenic were found to be the highest ecological risk factors for the basin reservoirs in the Thrace Part of the Marmara Region of Turkey. This situation was caused by the medicines and fertilizers used in agricultural areas from land use in the basin. Also, they are known as agricultural origin toxicants. $\mathrm{Cd}$ is one of the most present toxicants because many fertilizers used in Turkey were found to be over the limit values (Tokatli, 2019). Since there is no agricultural land in our study area, heavy metal concentrations were found low in all water samples.

It has been determined that different land uses statistically affect sodium and sulfur concentrations from chemical water quality parameters $(p<0.001)$. The highest concentrations of sodium $(6.56 \mu \mathrm{g}$ $\mathrm{Na} / \mathrm{L}$ ) and sulfur (26.72 $\mathrm{\mu g} \mathrm{S} \mathrm{/} \mathrm{L)} \mathrm{were} \mathrm{found} \mathrm{in} \mathrm{water} \mathrm{samples} \mathrm{ob-}$ tained from range areas while the lowest amounts $(1.90 \mu \mathrm{g} \mathrm{Na} / \mathrm{L}$ and $0.76 \mu \mathrm{g} \mathrm{S} / \mathrm{L}$ ) were found in forest areas. The $\mathrm{Na}$ concentration in the water samples obtained from all three land-use types is in the 1st water quality class. The sulfur concentration of water samples obtained from the forests is I. quality water, but riparian areas are found in class III water quality. However, it was found to have an intense concentration above the quality standards in the rangeland water sample. Increased sulfur concentration causes the taste and smell of the water to deteriorate and not to be of the standard of drinking and utilities (Öztürk \& Fakığlu, 2017). 
Usta (2011) found the effects of different land use on water quality in the Galyan Watershed Basin. The study stated that the $\mathrm{pH}$, $\mathrm{EC}, \mathrm{TN}, \mathrm{TP}, \mathrm{Ca}^{++}, \mathrm{Mg}^{++}$and $\mathrm{Na}^{+}$amounts in the waters decrease with the increase of range areas in a basin. Also, the $\mathrm{pH}, \mathrm{EC}, \mathrm{Ca}$, and $\mathrm{Mg}$ amounts in the water decrease when the Coniferous Forest areas increase. However, it was stated that $\mathrm{pH}, \mathrm{EC}, \mathrm{TN}, \mathrm{Ca}$, $\mathrm{Mg}$, and $\mathrm{Na}$ in water increased with the increase in the broadleaf forest areas. As mentioned earlier, several anthropogenic activities (tillage, fertilization, etc.) in the agriculture area firstly change the soil characteristics, and then this change is reflected in the stream water (Tong \& Chen, 2002). Bhat, Jacobs, Hatfield, \& Prenger (2006) noticed that the amounts of TN carried to stream water are expected to be high in broadleaf forest. More organic matter and microorganism activities in forest areas cause more element transition to soil and water (Türüdü, 1981).

\section{CONCLUSION}

In this study, the effects of land use differences on the chemical water quality were examined. The rain falls into the catchment basin where there are forest, range and riparian areas, and the rainwater mixes with groundwater by leaching organic and inorganic elements in the plant, root, litter layer and soil. These waters also join the drinking water reservoirs from here. When the chemical parameters of waters obtained from different land uses were examined, it was determined that the water obtained from the forest and riparian areas are more suitable for drinking and meet drinking water quality standards. However, the Sulfur concentration of water obtained from the range area $(26.72 \mu \mathrm{g} \mathrm{S} / \mathrm{L})$ exceeded drinking water quality standards and cannot be considered as drinking water. When the chemical characteristics of the Meydan Dam were examined according to the regulated water quality standards declared in water pollution laws, it is clear that the dam basin has a high water quality standard (Class I). A larger dam that could be built in this basin which would be able to supply quality water to meet the needs of the Kahramanmaraş metropolitan municipality. Land-use maps of the basin should be created before choosing the location to build dams for drinking water. In the selection of the catchment basin, authorities need to choose natural areas with vast forest lands, specifically away from any mining sites. The management and sustainability of different land uses (forest, agriculture, range and settlement) should be taken jointly by the competent authorities by considering the integrated watershed management approach in the basins that are supposed to supply drinking water.

Conflict of interests: The authors have no conflicts of interest to declare.

\section{Ethics committee approval: -}

\section{Funding: -}

Acknowledgments: This study was presented as an oral presentation at the $3^{\text {rd }}$ Water and Health Congress.

Disclosure: This study was presented at the " ${ }^{\text {rd }}$ International Water and Health Congress will be held $12^{\text {th }}-15^{\text {th }}$ November 2019 in Antalya".

\section{REFERENCES}

Allan, J. D., Erickson D. L. \& Fay J. (1997). The influence of catchment land use on stream integrity across multiple spatial scales. Freshwater Biology, 37, 149-161. [CrossRef]

Altun, L., Kezik, U., Kara, U. \& Babur, E. (2016). Potential of water purification of macka forest ecosystems in northeastern Turkey. $J$ Environ Prot Ecol, 17(2), 557-565.

Anonymous. (2012). Başkonuş Orman İşletme Şefliği, Başkonuş Orman Amenajman Planı. Kahramanmraş Orman Bölge Müdürlügü. Orman Genel Müdürlüğü (2012-2021).

Anonymous. (2016a). "İnsani tüketim amaçlı sular hakkında yönetmelik", Sağlık Bakanlığı. R. G. Tarihi: 17.02.2005, R.G. Sayısı: 25730. Ek 1 (Değişik ek: R.G-7/3/2013-28580). (Erişim tarihi: 10.08.2019).

Anonymous. (2016b). "Su Kirliliği Kontrolü Yönetmeliği", Çevre ve Orman Bakanlığı, R. G. Tarihi: 31.12.2004, R. G. Sayısı: 25687. Ek 1 (Değişik: R.G.-13/2/2008-26786). (Erişim tarihi: 10.08.2019).

Anonymous. (2016c). "Yüzeysel Su Kalitesi Yönetimi Yönetmeliğinde Değişiklik Yapılmasına Dair Yönetmelik", Orman ve Su İşleri Bakanlığı, R.G. Tarihi: 15.04.2015, R.G. Sayısı: 29327. (Erişim tarihi: 10.08.2019).

Babur, E. \& Kara, Ö. (2017). Su Kalitesi ve Orman Toprakları Arasındaki Illişkiler. 2nd International Water and Health Congress. Şubat 2017, Antalya.

Baker, A. (2005). Land Use and Water Quality. Encyclopedia of Hydrological Sciences. [CrossRef]

Bhat, S., Jacobs, J. M., Hatfield, K. \& Prenger, J. (2006). Relationships Between Stream Water Chemistry and Military Land Use in Forested Watersheds in Fort Benning, Georgia, Ecological Indicators, 6, 458-466. [CrossRef]

Bulut, C., Atay, R., Uysal, K., Köse, E. \& Çınar, Ş. (2010). Ulubat Gölü Yüzey Suyu Kalitesinin Değerlendirilmesi. Aquatic Sciences and Engineering, 25(1), 9-18

Cao, F., Li, X., Wang, D., Zhao, Y. \& Wang, Y. (2012). Effects of land-use structure on water quality in Xin' anjiang River. Environmental Science, vol. 34, no. 7, pp. 2582-2587.

Emiroğlu, Ö., Uyanoğlu, M., Başkurt, S., Sülün, Ş., Köse, E., Tokatlı, C., Uysal, K., Arslan, N. \& Çiçek, A. (2013). Erythrocyte deformations in Rutilus rutilus (Linnaeus, 1758) provided from Porsuk Dam (Turkey). Biological Diversity and Conservation, 6(1), 13-17.

Environmental Protection Agency (EPA) METHOD 3051A. (1998). Microwave assisted acid digestion of sediments, sludges, soils, and oils. https://www.epa.gov/ (accessed 03.03.2019).

Environmental Protection Agency (EPA) METHOD 200.7. (2001). Determination of metals and trace elements in water and wastes by inductively coupled plasma-atomic emission spectrometry. https:// www.epa.gov/ (accessed 03.03.2019).

Göksu, M. Z. L. (2003). Su Kirliliği, Çukurova Üniversitesi Su Ürünleri Fakültesi Yayınları, No:7, Adana, s. 232.

Guo, Q. H., Ma, K. M. \& Zhang, Y. (2009). Impact of land use pattern on lake water quality in urban region. Acta Eclologica Sinica, 29(2), 776787 (Chinese).

Gülçür, F. (1974). Toprağın Fiziksel ve Kimyasal Analiz Metodları. i.ü. Yayınları Yay No: 1970, Orman Fak. Yay. No: 201. Kurtuluş Matbaası, İstanbul.

Howarth, R. W., Billen, G., Swaney, D., Townsend, A., Jaworski, N., \& Lajtha K. (1996). Regional nitrogen budgets and riverine N \& P fluxes for the drainages to the North Atlantic Ocean. Natural and human influence. Biogeochemistry, 35, 75-139. [CrossRef]

Huang, J., Zhan, j., Yan, H., Wu, F. \& Deng, X. (2013). Evaluation of the Impacts of Land Use on Water Quality: A Case Study in The Chaohu Lake Basin. Hindawi Publishing Corporation. http://dx.doi. org/10.1155/2013/329187. [CrossRef]

Hunsaker, C. T. \& Levine, D. A. (1995). Hierarchical approaches to the study of water quality in rivers. Bioscience, 45, 193-203. [CrossRef]

Jordan, T. E., Correl, D. L. \& Weller, D. E. (1997). Effects of Agriculture on discharges of nutrients from coastal plain watersheds of Chesapeake Bay. Journal of Environmental Quality, 26, 836-848. [CrossRef] 
Ngoye, E. \& Machiwa, J. F. (2004). The influence of land-use patterns in the Ruvu river watershed on water quality in the river system, Physics and Chemistry of the Earth A, B, C, vol. 29, no. 15-18, pp. 1161-1166, 2004. [CrossRef]

NSTC. (2003). An Assessment of Coastal Hypoxia and Eutrophication in U.S. Waters, National Science and Technology Council, Committee on Environment and Natural Resources, (accessed 05.01.2018).

Öztürk, i. \& Fakıoğlu, M. (2017). İçme Sularında Tat ve Koku Giderimi. Teknik Kitaplar Serisi, ISKi.

Peierls, B. L., Caraco, N. F., Pace, M. L. \& Cole, J. (1991). Human influence on river nitrogen. Nature, 350, 386- 387. [CrossRef]

Pers, B. C. (2005). Modeling the Response of Eutrophication Control Measures in a Swedish Lake, Ambio, 34, 552-558. [CrossRef]

Puckett, L. (1995). Identifying the Major Sources of Nutrient Water Pollution. Environmental Science and Technology, 29, 408A-414A. [CrossRef]

Sliva, L. \& Williams, D. D. (2001). Buffer zone versus whole catchment approaches to studying land use impact on river water quality," Water Research, vol. 35, no. 14, pp. 3462-3472. [CrossRef]

Tokatli, C. (2019). Use of the potential ecological risk index for sediment quality assessment: A case study of Dam Lakes in the Thrace part of the Marmara Region. Aquatic Sciences and Engineering, 34(3), 9095. [CrossRef]
Tokatli, C., Solak, C. N., \& Yılmaz, E. (2020). Water quality assessment by means of bio-indication: A case study of ergene river using biological diatom index. Aquatic Sciences and Engineering, 35(2), 43-51. [CrossRef]

Tong, S. T. Y. \& Chen, W. (2002). Modeling The Relationship Between Land Use and Surface Water Quality. Journal of Environmental Management, 66, 377-393. [CrossRef]

TSE. (1997). TS-266, Türk İçme Suyu Standartları, Türk Standartları Enstitüsü, Ankara.

Türüdü, Ö. A. (1981). Trabzon Illi Hamsiköyü Yöresindeki Yüksek Arazide Aynı BakıdaBulunan Ladin Ormanı, Kayın Ormanı, Çayır ve Mısır Tarlası Topraklarının Bazı Fiziksel ve Kimyasal Özelliklerinin Karşılaştırmalı Olarak Araştırılması, KTÜ Orman Fak. Yayınları Yayın No: 13 , Trabzon.

Usta, A. (2011). Galyan-Atasu Barajı Havzasında Arazi Kullanımının Su Ve Toprak Özelliklerine Etkilerinin Araştııılması. Doktora Tezi, Karadeniz Teknik Üniversitesi, Fen Bilimleri Enstitüsü. Trabzon.

Walling, D. E. \& Fang, D. (2003). Recent Trends in the Suspended Sediment Loads of the World's Rivers. Global and Planetary Change, 39(1-2), 111-126. [CrossRef]

Yong, S. T. Y. \& Chen, W. (2002). Modeling the relationship between land use and surface water quality," Journal of Environmental Management, vol. 66, no. 4, pp. 377-393, 2002. [CrossRef] 